\title{
COMPARATIVE EFFECTS OF ORGANIC AND INORGANIC MANURE ON THE GROWTH AND DEVELOPMENT OF CUCUMIS SATIVUS
}

\author{
Ekwealor U. Kenneth ${ }^{1}$, Iroka F. Chisom ${ }^{1 *}$, Eze N. Hope ${ }^{1}$ and Okafor N. Patience ${ }^{2}$ \\ ${ }^{1}$ Department of Botany, Nnamdi Azikiwe University Awka, Anambra State. \\ ${ }^{2}$ Department of Biology Education, Federal College of Education Technical Umunze, \\ Nigeria.
}

*Corresponding Author: harlyz14@yahoo.com

Cite this article:

Ekwealor U.K., Iroka F.C., Eze N.H., Okafor N.P. (2021), Comparative Effects of Organic and Inorganic Manure on the Growth and Development of Cucumis Sativus. African Journal of Agriculture and Food Science 4(3), 51-58. DOI: 10.52589/AJAFSUMVFPNRE.

\section{Manuscript History}

Received: 14 July 2021

Accepted: 12 Aug 2021

Published: 9 Sept 2021

Copyright () 2020 The Author(s). This is an Open Access article distributed under the terms of Creative Commons AttributionNonCommercial-NoDerivatives 4.0 International (CC BY-NC-ND 4.0 ), which permits anyone to share, use, reproduce and redistribute in any medium, provided the original author and source are credited.
ABSTRACT: A study on the comparative effects of organic manure and inorganic fertilizer on the growth and development of Cucumis sativa was carried out at Nnamdi Azikwe University Awka. Randomized Complete Block Design was used for the study. $30 \mathrm{~kg}$ of sandy loam soil was used and different concentrations of organic manure were $0.5 \mathrm{~kg}$, $1.0 \mathrm{~kg}, 1.5 \mathrm{~kg}$ and $2.0 \mathrm{~kg}$, while $0.3 \mathrm{~kg}$ of inorganic manure was used to treat the soil. Growth parameters such as changes in length, girth, leaf area and the number of leaves were measured on weekly basis and recorded accordingly. The results on the effect of organic manure and inorganic manure on the leaf area of cucumber revealed that the $2 \mathrm{~kg}$ of organic manure gave the highest leaf area increase of cucumber from $9.33 \pm 0.306 \mathrm{~cm}^{2}$ in week 1 to $298.79 \pm 5.526 \mathrm{~cm}^{2}$ in week 6. The performance of $2 \mathrm{~kg}$ of organic manure is followed by $1.5 \mathrm{~kg}$ of organic manure which gave leaf area increase of cucumber from $8.97 \pm 0.351 \mathrm{~cm}^{2}$ in week 1 to $246.69 \pm 5.754 \mathrm{~cm}^{2}$ in week 6 . The control increased the least leaf area from $3.20 \pm 0.200 \mathrm{~cm}^{2}$ in week 1 to $96.08 \pm 5.562 \mathrm{~cm}^{2}$ in week 6 . Analysis of variance showed a significant difference $(p<0.05)$ in the leaf area of cucumber between treatments studied from week 1 to week 6 . Also, results on the effect of organic manure and inorganic fertilizer on the height of cucumber revealed that the $2 \mathrm{~kg}$ of organic manure gave the highest height increase of cucumber from $6.20 \pm 0.100 \mathrm{~cm}$ in week 1 to $99.60 \pm 0.200 \mathrm{~cm}$ in week 6 . The performance of $2 \mathrm{~kg}$ of organic manure is followed by inorganic manure which gave a height increase of cucumber from $5.33 \pm 0.058 \mathrm{~cm}$ in week 1 to $88.73 \pm 4.143 \mathrm{~cm}$ in week 6 . The control gave the least height increase from $3.33 \pm 0.153 \mathrm{~cm}$ in week 1 to $29.20 \pm 1.153 \mathrm{~cm}$ in week 6 . Analysis of variance showed a significant difference $(p<0.05)$ in the height of cucumber between treatments studied (that is the different rates of organic manure, inorganic manure and control) from week 1 to week 6. study shows that the treatment of inorganic fertilizer on the cucumber plant had a significant impact on cucumber while organic manure alone gave the highest stem height and stem girth of cucumber.

KEYWORDS: Cucumber, Organic manure, Inorganic fertilizer, Growth, Development, Nitrogen, Potassium, Phosphorus. 


\section{INTRODUCTION}

Organic manure is an essential source of nutrients for the soil as it contains a high amount of nitrogen, phosphorus, potassium and other essential nutrients (Oyewole and Oyewole, 2011). In contrast to chemical fertilizer, it adds organic matter to the soil which improves soil structure, nutrient retention, aeration, soil moisture-holding capacity and water infiltration (Dekissa and Allen, 2008). Organic manure such as cow dung, chicken manure etc helps to improve the soil by providing nutrients for growing crops and it also improves the soil quality because of its high organic matter content with available nutrients for plant growth. Although organic manure exists in readily available forms, cheap and easy to access, they need to be applied in large amounts to meet the nutrient requirement of crops (Prabu et al., 2003).

Cow dung is made up of digested grass and grain. It is high in organic material and nutrients. It contains about 3 per cent nitrogen, 2 per cent phosphorus, and 1 per cent potassium (3:2:1 NPK). It is said to contain a high level of ammonia and potentially dangerous pathogens, for this reason, it is usually recommended that it be aged or composted prior to its use as cow manure fertilizer. Cow manure adds a significant amount of organic material to the soil, it improves the overall health of the soil that produce healthy vigorous plants.

On the other hand, inorganic fertilizer is fertilizer mined from mineral deposits or manufactured from synthetic compounds. In the past years, inorganic fertilizer (N: P: K) was advocated for crop production to improve the low inherent fertility of the soil in the tropics since it provided readily available nutrients for plants but their use has not always been successful in the tropics due to the enhancement of soil acidity, easy leaching of nutrient, low organic matter status, reduced crop yield and degradation of soil physical properties.

NPK fertilizer is comprised primarily of nitrogen, phosphorus and potassium required for healthy plant growth. The agriculture industry relies heavily on the use of NPK fertilizer to meet the global food supply and ensure healthy crops but the environmental consequences and cost of this fertilizer makes them undesirable and also uneconomically out of reach to the poor farmers.

Titiloyer (1992) reported that the most satisfactory method of increasing plant yield was by a judicious combination of organic waste and inorganic fertilizer. As the integration of organic sources and synthetic sources of nutrients not only supply essential nutrients but also have some positive interaction with chemical fertilizer to increase their efficiency and thereby reduce environmental hazards (Bocchi and Tano, 1992). Murwira and Kirchman (1993) observed that nutrient use efficiency might be increased through the combination of organic manure and inorganic fertilizer.

A very common practice by farmers is the use of organic manure and inorganic fertilizer to raise the yield of crops, especially under improved husbandry. Farmers cannot produce their crops economically without adding to the soil, the element that helps boost their growth and yield.

According to Ogunkeyede and Akinlere (1995), fertilizers are added to the soil to encourage fast growth, boost yield and enrich the plant with the most important elements such as nitrogen, phosphorus and potassium. This study aims to compare the effect of cow dung manure and NPK 15:15:15 fertilizer on the growth of Cucumis sativus, by monitoring the germination and 
development process in order to ascertain the best treatment option for optimum growth and development of Cucumis sativus.

\section{MATERIALS AND METHOD}

\section{Study Site and Source of Materials}

The study was conducted in the departmental garden of the Botany Department, Nnamdi Azikiwe University Awka, Anambra state. The experiment was conducted using Randomized Complete Block Design, 18 potting bags were used and the bags were perforated at the base for easy drainage. Sandy loam soil was used. The plant sample (Cucumis sativus seeds also called cucumber seed) and N.P.K 15:15:15 were purchased from Anambra state Ministry of Agriculture and the plant seed was authenticated by a plant taxonomist in the departmental herbarium. The cow dung was sourced from a cattle farm at Agu-oye layout Okochi village Okpuno Awka.

\section{Procedure}

Three treatments were used each with thirty kilograms $(30 \mathrm{~kg})$ of soil. The treatments included: sandy loam soil treated with organic manure at different concentrations; $0.5 \mathrm{~kg}, 1.0 \mathrm{~kg}, 1.5 \mathrm{~kg}$, and $2.0 \mathrm{~kg}$, plant treated with inorganic fertilizer (NPK) after 21days, and plant not treated that served as the control. Each treatment was replicated three times. The potting bags filled with soil organic manure was first watered daily for one week to aid Ammonification before planting; thereafter four seeds were sown per bag. A peg was placed in each potting bag, making sure that the tip projects above the soil by $2 \mathrm{~cm}$, the tip of this peg served as a basement or position for measurements of height and girth. Following germination of the plants, inorganic fertilizer treatment was applied after 21days of growth. The control was not treated with either the organic or inorganic fertilizer; rather four seeds were planted in the moisturized soil. After one week of ammonification, it was ensured that the soil was aerated and not waterlogged before the planting was done. Growth parameters such as changes in length, girth, leaf area and the number of leaves were measured on weekly basis and recorded accordingly.

Plant Height: Height was measured with the use of a measuring tape starting from the base of the plant to the shoot apex and the values were recorded accordingly in centimetres.

Plant Girth: Stem girth was measured using a rope clung around the stem of each seedling and read against the graduated measuring tape and the values recorded accordingly (in centimetres).

Leaf Area: The length and breadth of the leaf were measure using a measuring tape and recorded accordingly in square centimetres. Leaf area was then calculated as;

\section{Leaf area $\left(\mathrm{cm}^{2}\right)=\mathrm{L} \mathrm{X} \mathrm{B}$}

Where:

$\mathrm{L}=$ length of Leaf

$\mathrm{B}=$ Breath of leaf 
Leaf Number: The leaves of every seedling in each replicate were counted and the mean per replicate was determined.

\section{Statistical Analysis}

Data collected were subjected to Analysis of variance (ANOVA) at a $0.05 \%$ level of significance and the mean separated by Duncan Multiple Range Test (DMRT). Statistical Package for Social Sciences (SPSS) version 20 statistical tool was used to run the analysis.

\section{RESULTS}

Table 1: Effect of Organic Manure and Inorganic Manure on Stem Height of Cucumber

\begin{tabular}{|c|c|c|c|c|c|c|}
\hline \multirow[b]{2}{*}{ Treatment } & \multirow[b]{2}{*}{ WK1 } & \multicolumn{4}{|c|}{ Weekly Heights of Cucumber (cm) } & \multirow[b]{2}{*}{ WK6 } \\
\hline & & WK2 & WK3 & WK4 & WK5 & \\
\hline CTRL & $3.33 \pm 0.153$ & $5.37 \pm 0.462$ & $11.17 \pm 1.193$ & $20.37 \pm 0.907$ & $25.73 \pm 0.757$ & $29.20 \pm 1.153$ \\
\hline $0 . \mathrm{M}(0.5 \mathrm{~kg})$ & $3.73 \pm 0.153$ & $6.23 \pm 0.493$ & $12.77 \pm 1.079$ & $22.87 \pm 1.358$ & $31.23 \pm 1.320$ & $34.30 \pm 1.473$ \\
\hline $0 . \mathrm{M}(1 \mathrm{~kg})$ & $4.53 \pm 0.153$ & $7.93 \pm 0.777$ & $16.00 \pm 1.510$ & $26.53 \pm 0.493$ & $44.97 \pm 0.208$ & $56.23 \pm 0.252$ \\
\hline $0 . \mathrm{M}(1.5 \mathrm{~kg})$ & $5.57 \pm 0.551$ & $10.47 \pm 0.907$ & $17.20 \pm 1.058$ & $28.50 \pm 1.300$ & $51.53 \pm 4.875$ & $68.67 \pm 6.490$ \\
\hline $0 . \mathrm{M}(2 \mathrm{~kg})$ & $6.20 \pm 0.100$ & $12.03 \pm 1.159$ & $25.53 \pm 1.422$ & $36.93 \pm 1.877$ & $68.43 \pm 1.704$ & $99.60 \pm 0.200$ \\
\hline I.M $(0.3 \mathrm{~kg})$ & $5.33 \pm 0.058$ & $10.67 \pm 0.115$ & $31.27 \pm 1.193$ & $44.67 \pm 1.721$ & $65.03 \pm 2.554$ & $88.73 \pm 4.143$ \\
\hline LSD & 0.452 & 1.307 & 2.231 & 2.418 & 4.331 & 5.760 \\
\hline P-VALUE & .000 & .000 & .000 & .000 & .000 & .000 \\
\hline
\end{tabular}

O.M= Organic Manure, $1 . M=$ Inorganic Manure, $C T R L=$ Control

The results on the effect of organic manure and inorganic manure on the height of cucumber revealed that the $2 \mathrm{~kg}$ of organic manure (cow dung) gave the highest height increase of cucumber from $6.20 \pm 0.100 \mathrm{~cm}$ in week 1 to $99.60 \pm 0.200 \mathrm{~cm}$ in week 6 . The performance of $2 \mathrm{~kg}$ of organic manure is followed by inorganic manure (N.P.K 15:15:15) which gave a height increase of cucumber from $5.33 \pm 0.058 \mathrm{~cm}$ in week 1 to $88.73 \pm 4.143 \mathrm{~cm}$ in week 6 . The control gave the least height increase from $3.33 \pm 0.153 \mathrm{~cm}$ in week 1 to $29.20 \pm 1.153 \mathrm{~cm}$ in week 6 . Analysis of variance showed a significant difference $(\mathrm{p}<0.05)$ in the height of cucumber between treatments studied (that is the different rates of organic manure, inorganic manure and control) from week 1 to week 6 (Table 1). 
Table 2: Effect of Organic Manure and Inorganic Manure on Stem Girth of Cucumber

\begin{tabular}{|c|c|c|c|c|c|c|}
\hline \multirow[b]{2}{*}{ Treatment } & \multirow[b]{2}{*}{ WK1 } & \multicolumn{4}{|c|}{ Weekly Stem Girths of Cucumber (mm) } & \multirow[b]{2}{*}{ WK6 } \\
\hline & & WK2 & WK3 & WK4 & WK5 & \\
\hline CTRL & $0.01 \pm 0.000$ & $0.05 \pm 0.000$ & $0.12 \pm 0.015$ & $1.32 \pm 0.065$ & $2.67 \pm 0.115$ & $3.92 \pm 0.115$ \\
\hline $0 . \mathrm{M}(0.5 \mathrm{~kg})$ & $1.02 \pm 0.010$ & $1.53 \pm 0.030$ & $1.77 \pm 0.030$ & $2.14 \pm 0.020$ & $3.30 \pm 0.050$ & $4.73 \pm 0.068$ \\
\hline $0 . \mathrm{M}(1 \mathrm{~kg})$ & $1.28 \pm 0.108$ & $2.26 \pm 0.550$ & $2.86 \pm 0.276$ & $4.38 \pm 0.711$ & $5.28 \pm 0.610$ & $6.22 \pm 0.280$ \\
\hline $0 . \mathrm{M}(1.5 \mathrm{~kg})$ & $2.37 \pm 0.208$ & $2.89 \pm 0.066$ & $4.14 \pm 0.645$ & $5.28 \pm 0.154$ & $6.92 \pm 0.654$ & $8.72 \pm 0.613$ \\
\hline $0 . \mathrm{M}(2 \mathrm{~kg})$ & $2.43 \pm 0.666$ & $3.75 \pm 0.589$ & $5.47 \pm 0.869$ & $7.37 \pm 0.520$ & $9.17 \pm 0.431$ & $11.30 \pm 0.391$ \\
\hline I.M $(0.3 \mathrm{~kg})$ & $0.88 \pm 0.104$ & $2.20 \pm 0.361$ & $2.57 \pm 0.416$ & $3.13 \pm 0.351$ & $4.10 \pm 0.2 .00$ & $5.40 \pm 0.624$ \\
\hline LSD & 0.518 & 0.644 & 0.866 & 0.700 & 0.741 & 0.732 \\
\hline P-VALUE & .000 & .000 & .000 & .000 & .000 & .000 \\
\hline
\end{tabular}

O.M= Organic Manure, $1 . M=$ Inorganic Manure, $C T R L=$ Control

The results on the effect of organic manure and inorganic manure on stem girth of cucumber revealed that the $1.5 \mathrm{~kg}$ of organic manure (cow dung) gave the highest stem girth increase of cucumber from $2.43 \pm 0.666 \mathrm{~mm}$ in week 1 to $11.30 \pm 0.391 \mathrm{~mm}$ in week 6 . The performance of $2 \mathrm{~kg}$ of organic manure is followed by $1.5 \mathrm{~kg}$ of organic manure which gave stem girth increase of cucumber from $2.37 \pm 0.208 \mathrm{~mm}$ in week 1 to $8.72 \pm 0.613 \mathrm{~mm}$ in week 6 . The control gave the least stem girth increase from $0.01 \pm 0.000 \mathrm{~mm}$ in week 1 to $3.92 \pm 0.115 \mathrm{~mm}$ in week 6 . Analysis of variance showed a significant difference $(\mathrm{p}<0.05)$ in the stem girth of cucumber between treatments investigated from week 1 to week 6 (Table 2 ).

Table 3: Effect of Organic Manure and Inorganic Manure on Leaf Number of Cucumber

\begin{tabular}{|c|c|c|c|c|c|c|}
\hline \multirow[b]{2}{*}{ Treatment } & \multirow[b]{2}{*}{ WK1 } & \multicolumn{4}{|c|}{ Weekly Leaf Number of Cucumber } & \multirow[b]{2}{*}{ WK6 } \\
\hline & & WK2 & WK3 & WK4 & WK5 & \\
\hline CTRL & $1.33 \pm 0.577$ & $4.00 \pm 1.000$ & $7.00 \pm 1.000$ & $13.33 \pm 1.528$ & $18.00 \pm 1.732$ & $19.67 \pm 2.082$ \\
\hline $0 . \mathrm{M}(0.5 \mathrm{~kg})$ & $2.00 \pm 1.000$ & $3.67 \pm 1.155$ & $8.33 \pm 2.309$ & $15.67 \pm 1.528$ & $21.67 \pm 0.577$ & $24.33 \pm 0.577$ \\
\hline $0 . \mathrm{M}(1 \mathrm{~kg})$ & $2.00 \pm 1.00$ & $3.33 \pm 1.528$ & $7.33 \pm 3.512$ & $12.00 \pm 6.00$ & $20.33 \pm 1.504$ & $25.00 \pm 3.000$ \\
\hline $0 . \mathrm{M}(1.5 \mathrm{~kg})$ & $2.00 \pm 1.000$ & $4.67 \pm 1.155$ & $10.33 \pm 2.517$ & $16.33 \pm 0.577$ & $26.33 \pm 0.577$ & $28.00 \pm 1.732$ \\
\hline $0 . \mathrm{M}(2 \mathrm{~kg})$ & $2.33 \pm 0.577$ & $8.00 \pm 1.000$ & $14.00 \pm 1.00$ & $20.33 \pm 2.517$ & $38.00 \pm 4.000$ & $55.33 \pm 5.033$ \\
\hline I.M $(0.3 \mathrm{~kg})$ & $2.33 \pm 0.577$ & $4.67 \pm 1.155$ & $12.33 \pm 1.528$ & $21.00 \pm 1.732$ & $31.67 \pm 4.509$ & $45.33 \pm 2.517$ \\
\hline LSD & NS & 2.097 & 3.866 & 5.153 & 8.906 & 10.484 \\
\hline P-VALUE & .701 & .000 & .010 & .013 & .003 & .000 \\
\hline
\end{tabular}

O.M= Organic Manure, $1 . M=$ Inorganic Manure, CTRL= Control, NS: Not Significant

The results on the effect of organic manure and inorganic manure on the leaf number of cucumbers revealed that the $2 \mathrm{~kg}$ of organic manure (cow dung) gave the highest leaf number increase of cucumber from $2.33 \pm 0.577$ in week 1 to $55.33 \pm 5$.033in week 6 . The performance of $2 \mathrm{~kg}$ of organic manure is followed by inorganic manure which gave leaf number increase of 
cucumber from $2.33 \pm 0.577$ in week 1 to $45.33 \pm 2.517$ in week 6 . The control gave the least leaf number increase from $1.33 \pm 0.577$ in week 1 to $19.67 \pm 2.082$ in week 6 . Analysis of variance showed a significant difference $(\mathrm{p}<0.05)$ in the leaf numbers of cucumber between treatments investigated from week 2 to week 6 (Table 3).

Table 4: Effect of Organic Manure and Inorganic Manure on Leaf Area of Cucumbers

\begin{tabular}{|c|c|c|c|c|c|c|}
\hline \multirow[b]{2}{*}{ Treatment } & \multirow[b]{2}{*}{ WK1 } & \multicolumn{4}{|c|}{ Weekly Leaf Area of Cucumber $\left(\mathrm{cm}^{2}\right)$} & \multirow[b]{2}{*}{ WK6 } \\
\hline & & WK2 & WK3 & WK4 & WK5 & \\
\hline CTRL & $3.20 \pm 0.200$ & $7.77 \pm 0.630$ & $19.14 \pm 1.378$ & $47.21 \pm 3.320$ & $85.08 \pm 8.947$ & $96.08 \pm 5.562$ \\
\hline $0 . \mathrm{M}(0.5 \mathrm{~kg})$ & $5.27 \pm 0.503$ & $17.55 \pm 1.720$ & $36.03 \pm 4.338$ & $83.57 \pm 4.927$ & $114.32 \pm 9.487$ & $125.75 \pm 4.435$ \\
\hline $0 . \mathrm{M}(1 \mathrm{~kg})$ & $6.80 \pm 0.361$ & $23.86 \pm 2.926$ & $48.12 \pm 5.948$ & $98.32 \pm 8.552$ & $166.48 \pm 8.570$ & $208.1 \pm 5.713$ \\
\hline $0 . \mathrm{M}(1.5 \mathrm{~kg})$ & $8.97 \pm 0.351$ & $33.79 \pm 2.416$ & $59.31 \pm 8.287$ & $102.96 \pm 9.876$ & $185.02 \pm 4.322$ & $246.69 \pm 5.754$ \\
\hline $0 . \mathrm{M}(2 \mathrm{~kg})$ & $9.33 \pm 0.306$ & $36.04 \pm 3.593$ & $76.64 \pm 4.316$ & $110.75 \pm 5.668$ & $205.32 \pm 5.037$ & $298.79 \pm 5.526$ \\
\hline I.M $(0.3 \mathrm{~kg})$ & $7.60 \pm 0.200$ & $15.20 \pm 0.400$ & $44.54 \pm 2.240$ & $63.63 \pm 3.200$ & $92.14 \pm 5.331$ & $125.81 \pm 9.563$ \\
\hline LSD & 0.599 & 4.032 & 8.849 & 11.446 & 14.536 & 16.428 \\
\hline P-VALUE & .000 & .000 & .000 & .000 & .000 & .000 \\
\hline
\end{tabular}

The results on the effect of organic manure and inorganic manure on the leaf area of cucumber revealed that the $2 \mathrm{~kg}$ of organic manure (cow dung) gave the highest leaf area increase of cucumber from $9.33 \pm 0.306 \mathrm{~cm}^{2}$ in week 1 to $298.79 \pm 5.526 \mathrm{~cm}^{2}$ in week 6 . The performance of $2 \mathrm{~kg}$ of organic manure is followed by $1.5 \mathrm{~kg}$ of organic manure which gave leaf area increase of cucumber from $8.97 \pm 0.351 \mathrm{~cm}^{2}$ in week 1 to $246.69 \pm 5.754 \mathrm{~cm}^{2}$ in week 6 . The control gave the least leaf area an increase from $3.20 \pm 0.200 \mathrm{~cm}^{2}$ in week 1 to $96.08 \pm 5.562 \mathrm{~cm}^{2}$ in week 6 . Analysis of variance showed a significant difference $(\mathrm{p}<0.05)$ in the leaf area of cucumber between treatments studied from week 1 to week 6 (Table 4).

\section{DISCUSSION}

Cucumber fruit is generally valued for its richness in mineral, dietary fibre and vitamins (Ipinmoroti et al., 2002). However, its cultivation and production in Africa are increasingly slowed down by soil fertility problems (Sinclair and Vadez, 2002). The result of this study shows that the organic and inorganic manure gave a greater yield than its control because the control lacks the nutrient that could boost the growth of the plant. This result is consistent with the study by Smailing (1993) that legumes respond well to adequate soil nutrients supplied by organic and inorganic fertilizers.

The organic manure treatments performed better both at the initial stage and end of the experiment while the control performed least. This is in support of Ipinmoroti et al. (2002) who recommended the use of organic manure and inorganic fertilizer for the sustenance of longterm cropping in the tropics.

The results also showed that Cucumber gave higher leaf area and number of leaves in organic manure and inorganic fertilizer treatments than the control. These results could be due to the 
synergy created between organic and inorganic fertilizer on the soil nutrients and biophysical properties (Peoples et al., 2005). Palm et al. (1997) reported that organic manure is reported to be a storehouse of nutrients especially nitrogen, while synthetic fertilizer is reported to be a ready source of available phosphorus. This implies that organic manure and NPK created a favourable soil and nutrient condition that triggered higher leaf area, number of leaves, and branches of cucumber.

Moreover, organic manure treatment had a huge influence on the stem height and stem girth most especially the treatment of $0.5 \mathrm{~kg}$ concentration than the inorganic fertilizer treatment and the control. This shows that cucumbers have a selective nutrient requirement for the different metabolic processes, in this case of stem height and stem girth.

\section{CONCLUSION}

This study shows that the treatment of inorganic fertilizer on the cucumber plant had a significant effect on cucumber while organic manure alone gave the highest stem height and stem girth of cucumber. This result is on a positive note that organic manure will help reduce the reliance on inorganic fertilizer which has an environmental problem, inaccessible and expensive. Hence, this study recommends a shift on reliance on inorganic fertilizers alone and encourages the use of organic manure for optimum by local cucumber farmers.

\section{Conflict Of Interest}

The authors declare no conflict of interest.

\section{REFERENCES}

[1]. Oyewole, C.I. and A.N. Oyewole (2011). Crop production and the livestock industry, the interplay; A case study of manure and crop production, Proceeding of the $16^{\text {th }}$ Annual Conference of Agricultural Society of Nigeria. 124-127.

[2]. Dekisssa, T.S. and J. Allen (2008). Effect of soil amendment with compost on growth and water use efficiency of Amaranth. In: Proceedings of the UCOWR/NIWR annual conference: international water resources: challenges for the $21^{\text {st }}$ century and water resources education, July 22-24, 2008, Durham, NC. 58.

[3]. Prabu, T., P.R. Narwadkar, A.K. Sanindranath and M. Rafi (2003). Effect of integrated nutrient management on growth and yield of plant CV.parbhani kranti. Orissa Journal Horticulture. 31(1):17-21.

[4]. Titiloye, E.O. (1992). The chemical composition of different sources of organic wastes and effects on growth and yield of maize. PhD Thesis University of Ibadan, Nigeria. 316.

[5]. Bocchi, S. and F. Tano. (1992). Effects of cattle manure and component of pig slurry on maize growth and production. European Journal of Agronomy. 3(3):235-241.

[6]. Murwira, H.K and Kirchman, A.K. (1993). Carbon and nitrogen mineralization of cattle manures subjected to different treatment in Zimbabwean and Swedish soils: soil organic matter dynamics and sustainability of tropical Agriculture. 189-198. 
[7]. Ogunkeyede, O.O. and K.O.S. Akinlere. (1995). A paper presented at the national workshop on prospects of markets Gardening and FADAMA vegetable production. 25.

[8]. Ipinmoroti, R.R., M.A. Daniel and C.R. Obatolu. (2002). Effect of organic mineral fertilizer on tea growth at Kusuku Mabia Plateau. Nigerian Journal of Agricultural Research. 3:180-183.

[9]. Sinclair, T.R. and V. Vadez. (2002). Physiological trait of crop yield Improvement in low N and P environments. Plant and soil. 245(1):1-15.

[10]. Smailing, E.M.A. (1993). Soil Nutrient Depletion in sub-Saharan Africa. In: Van Reutler H. and W.H. Prims (Eds). The role of plant nutrients for sustainable food crop production in Sahara Africa. The Netherlands: VK. 53-67.

[11]. Peoples, M.B., R.R. Gault, G.J. Scammell, B.S. Dear, J. Vigona, G.A. Sandral, J. Paul, E.C. Wolf and J.F. Angus. (2005). Effect of pasture management on the contributions of fixed $\mathrm{N}$ to the $\mathrm{N}$ economy of ley-farming systems. Australian Journal of Agriculture Resources. 49:459-474.

[12]. Palm, C.A., R.K. Myres and S.M. Nandwa. (1997). Combined use of organic and inorganic use of nutrient sources for soil fertility maintenance and replenishment. 1997. In: Replenishing soil fertility in Africa. A special edition. 